\title{
The Potential of Biomethane in Replacing Fossil Fuels in Heavy Transport-A Case Study on Finland
}

\author{
Anna Pääkkönen ${ }^{1,2, *}$, Kalle Aro ${ }^{3}$, Pami Aalto ${ }^{3}$, Jukka Konttinen ${ }^{1}$ and Matti Kojo ${ }^{3}$ (1) \\ 1 Faculty of Engineering and Natural Sciences, Tampere University, Korkeakoulunkatu 8, \\ 33720 Tampere, Finland \\ 2 MAB Powertec Oy, Finlaysoninkatu 7, 33210 Tampere, Finland \\ 3 Faculty of Management and Business, Tampere University, Kanslerinrinne 1, 33100 Tampere, Finland \\ * Correspondence: anna.paakkonen@tuni.fi
}

Received: 10 July 2019; Accepted: 25 August 2019; Published: 30 August 2019

\begin{abstract}
Electrification is a frequently discussed solution for reducing transport related carbon dioxide emissions. However, transport sectors such as aviation and heavy-duty vehicles remain dependent on on-board fuels. Here, biomethane is still a little exploited solution, and the case of heavy-duty vehicles is particularly underappreciated despite the recent technical advances and potentially notable emission reductions. This paper discusses the potential of biomethane in heavy-duty road transport in the case of Finland, where the utilization rate is low compared to the technical potential. To this end, the potential of biomethane production through both anaerobic digestion and gasification was calculated in three scenarios for the heavy-duty transport fleet, based on the literature values of biomethane potential and truck class fuel consumption. The authors find that approximately half of the heavy-duty transport in Finland could be biomethane fueled by 2030. The estimated production costs for biomethane (81-190€/MWh) would be competitive with the current consumer diesel price (152 $€ / \mathrm{MWh})$. Utilizing the total biomethane potential in heavy-duty transport would furthermore decrease the respective carbon dioxide emissions by $50 \%$. To accelerate the transition in the heavy-duty transport sector, a more comprehensive political framework is needed, taking into account both production and consumption.
\end{abstract}

Keywords: renewable transport fuels; biomethane; carbon emission reduction; heavy-duty transport; transition; Finland; anaerobic digestion; wood gasification

\section{Introduction}

The transport sector is responsible for $14 \%$ of global $\mathrm{CO}_{2}$ emissions [1]. This share is set to increase further with economic growth in the developing countries [2]. In 2015, approximately half of total oil end use worldwide (49.7\%) was for transport [3]. At the same time, reducing the utilization of fossil fuels in all sectors is essential to reduce the emissions of $\mathrm{CO}_{2}$ and other greenhouse gases (GHGs) in order to combat global warming. Several European countries are considering bans on fossil fuelled passenger vehicles. Norway aims to achieve such a ban by 2025 alongside severe emission reductions for all vehicle classes by 2030 [4]. Similar plans also exist in France, Ireland, Sweden, Germany, and the UK, while in Finland the issue was discussed in connection with the 2019 parliamentary elections.

The electrification of transport is a frequently discussed solution for reducing GHG emissions in this sector. For passenger and medium-duty vehicles, electrification will be the most efficient emission reduction technology, assuming a high share of renewable low carbon power in the electric energy system. However, aviation, shipping, and a significant part of heavy-duty transport will remain dependent on on-board, high energy density transportable fuels for a considerable time to come $[5,6]$. In this article, we focus on the provision of low-carbon fuels for heavy-duty transport. While this is a 
global policy challenge, it is typically a more acute need for countries with low population density or with long distances between major concentrations of raw materials and sites of production and consumption. One study suggests that, in particular, countries where heavy truck-trailer combinations are widespread require solutions since such combinations are difficult to electrify even with high battery capacity [7]. Electric road systems, for their part, require very high investments and are unlikely to be able to serve all traffic needs [7].

In short, because it is unlikely that one solution for delivering low-carbon heavy transport will be applicable across all countries [6,7], several options need to be explored, including gaseous fuel solutions. Particularly in the European context, the considerable, yet largely unexploited technical potential of biomethane, or upgraded biogas, is one such option with several raw material streams available $[8,9]$.

\subsection{Background}

Biomethane is currently emerging as one viable solution for the heavy-duty transport sector [10-12], with comprehensive reviews of its benefits and constraints [13,14], and of the required heavy-duty vehicle fleet [15]. The European biomethane market comprises $90 \%$ of the global supply [16] and has grown seven-fold since 2000 [17]. Production can be doubled by $2030[8,17,18]$. The global potential is also promising. Using energy plants for the production of biogas has a better energy output per unit area than using the same plant-based raw material for producing liquid biofuels-which is so far remains the preferred solution in several countries around the world owing to its relative compatibility with vehicles using oil-based fuels. While in this respect it is possible to view biogas as a renewable fuel with a great deal of potential, its competitiveness can further be enhanced by also using the associated $\mathrm{CO}_{2}$ for commercial applications in numerous sectors [19].

For the use of biogas in transport, biomethane can be either pressurized (200 bar) or liquefied. Unlike hydrogen $\left(\mathrm{H}_{2}\right)$, which is constrained by costs, availability of vehicles and deficiencies in the transport and storage infrastructure [20], biomethane can be used in existing systems where natural gas methane $\left(\mathrm{CH}_{4}\right)$ is utilized. Suitable gas fuelled heavy traffic vehicles are commercially available, including so-called dual fuel (diesel/NG diesel for ignition and as a fuel) and spark ignition engines (only NG) $[10,11]$. The scenario of the Natural and Bio Gas Vehicle Association Europe (NGVA) expects the number of methane fuelled trucks to increase from 9000 to 480,000 by 2030, reaching a $25 \%$ market share, while liquefied natural gas (LNG) vehicles would take up a $10 \%$ share of the market [21]. The main constraint in promoting gas fuelled heavy trucks is the approximately $30-40 \%$ higher purchase price compared with fossil fuelled trucks [10], depending on the equipment [22-24].

A life cycle assessment has found that biomethane solutions, when used to power Euro6 buses, generally have a lower environmental impact than their main competitors-including liquid biodiesels-in terms of global warming, stratospheric ozone depletion, photochemical oxidant formation, acidification potential, and eutrophication potential [14]. Kalinichenko et al. [19] find crop-based biogas to provide a greater amount of vehicle fuel energy than the biodiesel or ethanol options. According to Hijazi et al. [25] and Baldino et al. [8], the raw material used for producing biomethane is crucial to the environmental sustainability of the fuel. Differences exist, for example, between crop-based and animal manure-based raw material, while the storing, management and production technologies also have a role. Livestock manure offers the greatest technical potential of biomethane in the EU compared with other raw materials, constituting $43 \%$ in the transport use case $[8,25]$.

The use of biomethane for transport has to compete with its use for power and heat, where biogas is more cost-efficient than in the transport sector when considering conceivable financial incentive structures [8] - while biogas can also be used to produce chemicals. However, the current incentives typically prioritize low carbon power production, not the heat or transport sectors. The existing transport sector incentives focus mostly on electric vehicles, which in Ireland, for example, enjoy sixteen-fold incentives compared to a natural gas vehicle operating on biomethane [26]. Moreover, since the transport case requires more complex infrastructure than the heating case, for example, 
filling stations, higher incentives would be natural [26]. Great energy efficiency and environmental benefits exist in the transport use case [9], including minimization of particle emissions and reduction of emissions in agriculture [26].

In the EU context, biomethane-based transport is at its most advanced in the case of Sweden, with half of biogas production used for transport [19]. Börjesson et al. [11] focus on the system level (per vehicle $\mathrm{km}$ ), bypassing the question of the actual number of vehicles. Ammenberg et al. [27] address the demand side actors and policies as well as the supply and distribution side through expert interviews in Stockholm County in Sweden. Biogas was found to have potential for buses and taxis, while utilization for heavy fuel transport was only mentioned as a future possibility. In addition, Lönnqvist et al. [28] explored the potential for biogas produced in anaerobic digestion (AD) in Stockholm County based on a survey of key actors. Jensen et al. [29] examined three biogas production scenarios in Denmark with a focus on commercial light and heavy-duty vehicle utilization, using three different technology assumptions for $\mathrm{AD}$ biogas production and assuming a 100\% share for biomethane fuelled heavy-duty vehicles. Uusitalo et al. [30] found biogas a potent transport fuel in Finland in view of its cost-effectiveness (calculated from the point of view of the gas grid owner), as well as GHG and particle emission reductions, but they did not directly examine the heavy-duty transport sector.

\subsection{Scope of the Paper}

This article breaks new ground by examining biomethane solutions in the context of heavy-duty transport, which so far has been little studied. Finland is presented as a typical case within a larger group of countries [31], wherein the heavy-duty transport sector is relatively large [32], showing a growing trend [33] (Countries meeting these criteria include, for example, France, Poland, Portugal and Spain) and in particular, where truck-trailer combinations are widespread [7]. Crucially, no studies have been published that include a vehicle class analysis of this case. The transport sector accounts for $20 \%$ of Finland's GHG emissions [34], while the country's exports consist predominantly of transport intensive commodities, including forest, chemical and metal industry products as well as machinery and vehicles. The presence of the forestry industry in Finland enables the production of liquid or gaseous biofuels from the industry's side-products. Consequently, liquid biofuels are a key part of the national energy and climate strategy, where biogas is also mentioned [35]. Yet the large-scale production of liquid biofuels is associated with much-discussed problems. Production from forest-based biomass may become limited by the availability of suitable raw material, and may have negative implications for the carbon sink, while the large-scale use of crop-based raw materials risks competing with food production $[8,20]$.

NG vehicles so far represent a niche sector in Finland, numbering only 3600 in 2017 [36]. However, Finland's techno-economic potential for biogas is large, estimated at $10 \mathrm{TWh}$ [37], making it larger for the transport use case than Sweden, the current leader, and twelfth largest in the EU [8]. Finland's 2016 Energy Strategy foresees the gasification of woody biomass for producing transport fuel as part of the $40 \%$ target for renewable fuels by 2030 [35]. The key constraints for the low utilization rate of the biogas potential include limitations in the distribution network and economic feasibility [38]. Moreover, Huttunen et al. [39] identify inadequate policy cohesion resulting from conflicting political targets and policy instruments. Winquist et al. [40] find some improvement in the recognition of biogas and the related benefits in recent policy documents, also outside of the energy sector. However, actual objectives and measures to promote biogas usage remain very generic. At the same time, significant additional potential exists for increasing biogas production from forest residues and agricultural by-products that could further improve Finland's raw material base. In the case of Sweden, Börjesson found that the realization of similar potential requires improved political guidance and regulation for this production not to conflict with environmental goals [41]. Moreover, for both Sweden and Norway, a need has been identified to co-ordinate the regulatory system and to provide subsidies to enable the most environmentally advantageous use of biogas [42,43]. 
This paper seeks to contribute to this debate by first assessing how high a share of Finland's heavy-duty transport could be biomethane fuelled. Drawing upon a pilot study on the potential of AD biogas for heavy traffic in Finland [44], this study uses an illustrative vehicle fleet model and calculates three different scenarios for a biomethane fuelled heavy-duty transport fleet. The biomethane potential was estimated based on the values in the existing literature of available raw material from AD processes as well as from woody biomass gasification. In addition, an estimate of $\mathrm{CO}_{2}$-emission reduction/ton is provided. In light of the results, this paper also discusses the respective constraints for biomethane production, delivery infrastructure and policies. Our primary research questions are:

(1) How large a share of heavy-duty road transport could the techno-economic potential of biomethane cover?

(2) What would be the cost of biomethane utilization for the heavy-duty truck fleet?

(3) How much transport related $\mathrm{CO}_{2}$ (and other) emissions could be avoided?

The biomethane potential suitable for the heavy-duty transport sector was found to be 7.4 TWh annually, which is substantial in the context of Finland. Depending on the priority order of vehicle classes, domestic biomethane could fuel as many as $66 \%$ of the vehicles in the current heavy vehicle fleet. Utilizing the entire potential of biomethane in the heavy-duty transport sector was found to halve the sector's GHG emissions as well as its $\mathrm{NO}_{\mathrm{x}}$-emissions, regardless of the scenario chosen. Economic analyses conducted to ascertain the theoretic magnitude of the financial investments required conclude that biomethane production (81-190€/MWh) would be competitive with the current consumer price for diesel (152 $€ / M W h)$. However, limited fuelling and delivery infrastructure, in addition to the small number of gas operated vehicles currently in use, imply that additional investments will also be required over and above biomethane production alone. Biogas has remained a niche technology in Finland, as both production and usage levels have remained low. The biogas production chain is characterized by a high level of uncertainty stemming from political incoherence between targets and means, as well as a low level of local co-operation. A more comprehensive and cross-sectoral framework is required to address obstacles to production and demand simultaneously, and to trigger a transition in heavy-duty road transportation in Finland. The results provide insights beyond Finland to other EU Member States by adjusting the vehicle classes, availability of biomethane and features of biogas policy-making according to the respective characteristics of each case.

\section{Methods, Materials and Assumptions}

A case study on biomethane solutions in the heavy-duty transport sector in Finland is reported here. Single case studies are particularly useful in little explored areas such as those discussed herein. They can generate observations to be subsequently explored in other typical cases [31] -in this context, heavy transport intensive countries with a relatively high biomethane potential, of which there are many in the EU. As suggested above, Finland is a somewhat difficult case in this group owing to the dominant role of the forest industry and, hence, a vested interest in liquid biofuels [45], while the widespread use of truck-trailer combinations curtails the prospects for electrification and necessitates considering several options, including biomethane. In other words, if biomethane solutions are found to be readily applicable in Finland, it is reasonable to expect the same for other cases in this group of countries. However, prospective comparisons must recognize the regional and local variation in the raw material, the distance to production sites and the effectiveness of transport [14,19,46,47]. Yet the authors expect the procedures used to be replicable and the results to be applicable to other countries in this group after adjustment for vehicle class, raw material base, and transport conditions.

The observations in this paper concern the production and potential of biomethane, its use in the heavy-duty traffic fleet in three different scenarios and the respective policy needs. All calculations represent theoretical process values. In addition, the authors calculated the amount of biomethane potential for gasification. The analysis of the constraints and required policies for the implementation of biogas solutions in Finland draws upon the literature available. 


\subsection{Assumptions on the Production of Biomethane}

$\mathrm{AD}$ processes can utilize residual biomaterial such as municipal bio-waste, sewage sludge or agricultural residues, resulting mainly in $\mathrm{CH}_{4}\left(50-70\right.$ vol-\%) and $\mathrm{CO}_{2}$ (30-50 vol-\%). Prior to utilization as a transport fuel, $\mathrm{CO}_{2}$ and other impurities must be removed by means of chemical or physical absorption, membrane separation, adsorption on a solid surface, cryogenic separation or chemical conversion [48-50]. In biomass gasification, the main product is $\mathrm{H}_{2}(40-50 \mathrm{vol}-\%$ of the dry product gas) that can be utilized directly as a transport fuel or further reacted catalytically or biologically with $\mathrm{CO}$ or $\mathrm{CO}_{2}$ to form $\mathrm{CH}_{4}$. Other gasification products include $\mathrm{CO}$ (typically 21 vol-\%), $\mathrm{CO}_{2}(15$ vol- $\%)$ and $\mathrm{CH}_{4}(10 \mathrm{vol}-\%)$ [47,51]. Commercial projects for transport fuel production via biomass gasification include GoBiGas in Sweden and GAYA in France [52] (Figure 1). Due to limitations of space, we do not consider power-to-gas technologies here, which can also be used to produce biomethane.

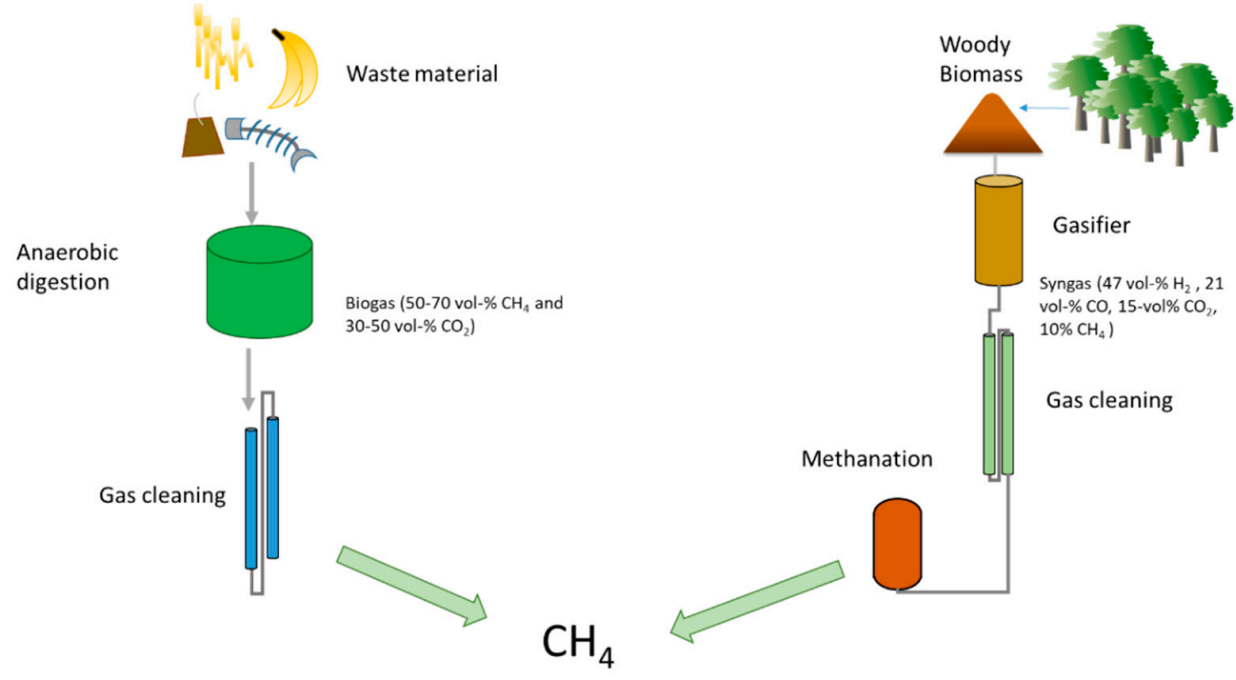

Figure 1. Simplified production paths for biomethane.

In 2017 there were 71 biogas production sites in Finland. Total production including collection from landfill sites was approximately $700 \mathrm{GWh}$ [53], of which only $30 \mathrm{GWh}$ was used as transport fuel. As of 2018, a mere 708 gas fuelled vehicles ran on natural gas (NG) only, and 2925 on both NG and petrol. Most of these vehicles were passenger vehicles. Only $18 \mathrm{NG}$ and 75 dual fuel trucks were registered. In 2017, there were altogether 3,099,566 cars, vans and trucks in Finland [36]. The potential for the expansion of the fleet of gas fuelled vehicles is considerable.

In this paper it is assumed that all the biomethane available to be used solely for heavy-duty transport, originating from both AD of waste material and gasification of woody biomass. Furthermore, based on [37], the techno-economic biomethane potential from AD in Finland is estimated to be $10 \mathrm{TWh}$. The amount of available woody biomass for transport fuels is expected to be $4 \mathrm{Mm}^{3}$ by 2030 according to the Finnish Government's estimate as calculated by the Ministry of Employment and the Economy for the country's 2016 Energy Strategy [35]. In addition, it is assumed that the wood contains 30\% of moisture, higher heating value (HHV) is $20 \mathrm{MJ} / \mathrm{kg}$ and average mass $238 \mathrm{~kg} / \mathrm{m}^{3}$ [54]. The amount of syngas from woody biomass can be calculated based on cold gas efficiency $\eta_{G}$ [47]:

$$
\eta_{G}=\frac{\dot{M}_{g} L H V_{g}}{\dot{M}_{b} L H V_{b}}
$$

where $M_{g}$ is the mass flow of product gas, $L H V_{g}$ is the lower heating value of the product gas, $M_{b}$ is the mass flow of wood, and $L H V_{b}$ the lower heating value of wood. In this study, $\eta_{G}=0.7$ based on $[47,55]$. The amount of available biomethane from wood gasification for its part is based on typical wood syngas composition (dry basis) (Table 1 ). 
Table 1. Typical wood gasification product gas composition $[47,51]$ and lower heating values (LHV) of the gas components.

\begin{tabular}{ccc}
\hline Compound & Vol-\% & LHV (kJ/mol) \\
\hline $\mathrm{H}_{2}$ & 47 & 241.8 \\
$\mathrm{CO}_{2}$ & 21 & - \\
$\mathrm{CO}$ & 15 & 283 \\
$\mathrm{CH}_{4}$ & 10 & 802.3 \\
$\mathrm{C}_{\mathrm{x}} \mathrm{H}_{\mathrm{y}}$ & 4 & \\
$\mathrm{~N}_{2}$ & 3 & - \\
sum & 100 & \\
\hline
\end{tabular}

The LHV of the syngas was calculated as a weighted average based on the gas composition and LHV of each of the gas components (Table 1). For gases, the volume fraction equals the molar fraction.

Syngas typically contains contaminants such as tars, solid particles and acids, which must be removed before further processing. Cleaning methods usually include cyclones, wet scrubbers and catalytic steps [56,57]. $\mathrm{H}_{2}$ and $\mathrm{CO}$ as well as $\mathrm{CO}_{2}$ from the syngas can be further reacted to $\mathrm{CH}_{4}$. The overall reactions can be simplified as Equations (2) and (3):

$$
\begin{gathered}
3 \mathrm{H}_{2}+\mathrm{CO} \rightarrow \mathrm{CH}_{4}+\mathrm{H}_{2} \mathrm{O} \\
4 \mathrm{H}_{2}+\mathrm{CO}_{2} \rightarrow \mathrm{CH}_{4}+2 \mathrm{H}_{2} \mathrm{O}
\end{gathered}
$$

Both reactions are exothermic (e.g., demand heat). The conversion of $\mathrm{CO}$ and $\mathrm{CO}_{2}$ (Equations (2) and (3)) was assumed equal to 1 [58]. Methanation of $\mathrm{CO}$ and $\mathrm{CO}_{2}$ include several reactions [52,59], however the overall reactions were found to be sufficient for the purposes of this study.

Since the amount of $\mathrm{H}_{2}$ in the syngas (Table 1 ) does not suffice for reacting all the $\mathrm{CO}$ and $\mathrm{CO}_{2}$ from the syngas, we preferred the methanation of $\mathrm{CO}$ (Equation (2)). Any excess $\mathrm{H}_{2}$ left from (Equation (2)) would then be utilized in $\mathrm{CO}_{2}$ methanation (Equation (3)). Several methods for methanation exist, including fixed and fluidized bed reactors, structured reactors, as well as slurry reactors [52]. A more detailed description of the $\mathrm{CO}$ and $\mathrm{CO}_{2}$ methanation technologies can be found in [52,59]. The LHV of methane is $802.3 \mathrm{MJ} / \mathrm{kmol}$. For the sake of simplicity, the energy losses from gas purification and pressurization were ignored.

\subsection{Assumptions Regarding Heavy-Duty Traffic: Vehicle Model and Scenarios}

The travelling distance estimates for the three existing commercial manufacturers of gas fuelled heavy-duty vehicles vary between 1000 and $1600 \mathrm{~km}$ [22-24]. The total energy consumption of trucks in Finland (2017) was 14.1 TWh [60], which exceeds the biomethane potential available (10 TWh). In order to examine the most effective scenario for biomethane in heavy-duty transport, the heavy transport trucks were divided into three vehicle classes, namely:

Light duty (LD) including delivery vans, refuse collection vehicles and other single unit trucks $<18 \mathrm{t}$ Medium duty (MD) including semi-trailer combination vehicles $>18 \mathrm{t}<60 \mathrm{t}$

Heavy duty (HD) including all articulated vehicles $>60 \mathrm{t}$

In 2017, the combined mileage of all the heavy-duty vehicles in Finland was 3,369,642,891 km [60] and was expected to increase $6 \%$ from the 2012 levels by 2030 [61]. The number of vehicles and the mileage of each vehicle class are presented in Table 2. [62] 
Table 2. Number of vehicles and average mileage of the vehicle classes [62].

\begin{tabular}{ccc}
\hline Truck Class & Number of Vehicles & Mileage per Vehicle $\mathbf{( k m / a )}$ \\
\hline LD & 65,616 & 19,476 \\
MD & 5652 & 80,060 \\
HD & 18,123 & 73,358 \\
\hline
\end{tabular}

The potential number of biomethane fuelled trucks was examined in three scenarios with different classes of target vehicles. The number of vehicles in each scenario was calculated on the basis of maximum quantities of biomethane theoretically available.

The target vehicle class in scenario I was LD trucks. First, the number of LD trucks that could be run with biomethane was calculated based on mileage (Table 2) and fuel consumption (Table 3). If the available volume of biomethane were to exceed the needs of the maximum number of LD trucks (Table 2), the next target class would be MD trucks. Were some biomethane potential still to remain, it would be used for as many HD trucks as possible.

Table 3. Average truck diesel consumption (kWh/100 km) $[60,63]$.

\begin{tabular}{ccccc}
\hline & \multicolumn{2}{c}{ Highway } & \multicolumn{2}{c}{ Freeway } \\
\hline Truck Class & Empty Load & Full Load & Empty load & Full Load \\
\hline LD & 173 & 207 & 207 & 283 \\
MD & 246 & 374 & 306 & 498 \\
HD & 335 & 553 & 424 & 770 \\
\hline
\end{tabular}

The target truck class in scenario II was HD, then MD and as many LD trucks as possible and in scenario III, the share of biomethane fuelled vehicles was divided equally between all classes (\%).

The vehicle fuel consumption and theoretical amount of biomethane fuelled heavy transport vehicles was based on the relevant literature. Average fuel consumption (Table 3) of the chosen vehicle classes was based on diesel truck measurements by [63] and statistical data by [60].

The average energy $(\mathrm{kWh} / 100 \mathrm{~km})$ consumption per vehicle class was calculated as:

$$
D_{e} *\left(b_{f} * c_{f r, e}+b_{h}{ }^{*} c_{h, e}\right)+D_{f} *\left(b_{f r} * c_{f r, f}+b_{h} * c_{h, f}\right)
$$

where $\mathrm{D}$ is the mileage fraction (empty or full load), b is the road fraction (highway or freeway), and c is the fuel consumption [1/100 km]. The subscript e indicates empty load, $\mathrm{f}$ full load, fr the freeway, $\mathrm{h}$ highway, and d diesel. Empty running average $28 \%$ of total mileage was based on [64]. For the sake of simplicity, it was assumed that for the rest of the mileage the trucks run on full load.

The trucks were assumed to be driving $80 \%$ highway, $20 \%$ freeway [65]. The average consumption for biomethane trucks was assumed to be $18 \%$ higher than for diesel fuelled trucks [11]. However, gas truck manufacturers claim that the fuel economy of gas fuelled trucks equals that of diesel equivalents [23] or exceeds it [24]. However, preferring to err on the side of caution, we assumed a lower efficiency for biomethane trucks.

\subsection{Assumptions Concerning Economic and Emission Saving Analysis}

Our estimate for the overall costs of transforming the heavy transport fleet to biogas is tentative. A detailed calculation regarding the production and distribution costs as well as $\mathrm{CO}_{2}$ savings of biomethane in the whole transport fleet in the Swedish context can be found in [11], while these results can be expected to be largely applicable to the Finnish case.

According to the International Renewable Energy Agency (IRENA) [12], the main constraint regarding biomethane as a transport fuel is currently the production cost, which mainly depends on the feedstock used. Here, this study proceeded from the expected biogas potential (10 TWh) of Finland 
and for AD production facilities followed the IRENA estimate [66] of the investment costs to vary between $2640-5540 € / \mathrm{kW}$. For wood gasification plants, the chosen values refer to the experiences of the GoBiGas plant in Gothenburg, Sweden [47], with $8250 € / \mathrm{kW}$ of gas production capacity. Since this is a pilot plant, the cost will most likely decrease once the technology matures. Yet again to err on the side of caution, this more conservative reference value was chosen. Plant investment costs refer to overnight building costs. Gas filling stations are assumed to be located by the plant site and are included in the overnight costs of the plants. For both types of biomethane plants (AD and gasification), the yearly operational hours were assumed to be $8000 \mathrm{~h}$. The yearly share of investment costs was calculated based on the annuity method with the assumption of $4 \%$ investment interest and plant lifetime of 20 years. Based on [11], the assumed production costs for AD biomethane is approximately $57 € / \mathrm{MWh}$ and for gasification biomethane $72-114 € / \mathrm{MWh}$, depending on the gasification technology chosen (direct or indirect gasification). The equivalent diesel fuel price was calculated from consumer diesel price $(1.4 € / \mathrm{L})$ [67], energy content of diesel $(11.5 \mathrm{MWh} / \mathrm{t})$, and diesel density $(0.08 \mathrm{~kg} / \mathrm{L})$. Since the calculations are based on assumptions in the literature, a sensitivity analysis for investment and production costs was performed by changing one parameter at a time by $\pm 30 \%$ in order to calculate whether investment or operational and fuel costs affect the overall costs of biomethane more.

The amount of $\mathrm{CO}_{2}$-equivalent and $\mathrm{NO}_{\mathrm{x}}$ emissions for diesel trucks (Table 4) were based on emission calculations data by VTT, the Technical Research Centre of Finland Ltd. [60], using standard EN 16258. The amount of $\mathrm{CO}_{2}$-equivalent emissions for each vehicle class was determined by substituting energy consumption in Equation (4) with emissions. As a rough estimate, the $\mathrm{CO}_{2}$ emission of biomethane vehicles can be expected to be approximately $80 \%$ less than that of diesel trucks, depending on the calculation method used (ISO vs. RED) [11]. The $\mathrm{NO}_{x}$ emissions of biomethane fuelled vehicles are reported to be $86 \%$ lower [10] than those of diesel fuelled vehicles, while the fine dust emissions and noise levels are also lower for gas fuelled vehicles [12]. The total $\mathrm{CO}_{2}$ and $\mathrm{NO}_{\mathrm{x}}$ emissions for scenarios I-III were determined on the basis of the number of biomethane and diesel fuelled trucks in each scenario.

Table 4. Average $\mathrm{NO}_{\mathrm{x}}$ and $\mathrm{CO}_{2}$-equivalent emissions for the truck classes running with diesel $[\mathrm{g} / \mathrm{km}][60]$.

\begin{tabular}{ccccccccc}
\hline \multicolumn{4}{c}{$\mathrm{NO}_{\mathbf{x}}[\mathrm{g} / \mathrm{km}]$} & \multicolumn{3}{c}{$\mathrm{CO}_{2}$-eqv. $[\mathrm{g} / \mathbf{k m}]$} \\
\hline \multicolumn{4}{c}{ Highway } & \multicolumn{2}{c}{ Freeway } & \multicolumn{2}{c}{ Highway } & \multicolumn{2}{c}{ Freeway } \\
\hline Truck & Empty & Full & Empty & Full & Empty & Full & Empty & Full \\
Class & Load & Load & Load & Load & Load & Load & Load & Load \\
\hline LD & 2.2 & 2.8 & 3.4 & 4.5 & 402 & 507 & 531 & 815 \\
MD & 4.3 & 5.3 & 6.9 & 9.7 & 630 & 962 & 965 & 1662 \\
HD & 4.7 & 6.5 & 8.3 & 14.0 & 834 & 1319 & 1298 & 2376 \\
\hline
\end{tabular}

\subsection{Limitations of the Methodology}

Limitations of the methodology stem mainly from the vehicle class categorization. As each of the three vehicle classes examined includes a fairly wide range of vehicles, a more detailed analysis could be provided by sub-dividing the vehicle classes into more specific analytical units. Moreover, the assumptions regarding average mileages, loading levels (full/empty) and relative shares of highway and freeway do not fully reflect the differences in the use of different types of heavy vehicles. Light delivery trucks, for example, often operate within a certain area and could have more predictable routes in their operations than the other types of vehicles considered here. Therefore, it can be expected that the share of freeway use is higher in the case of such vehicles than the average value would suggest.

Another limitation is utilizing the average values for fuel consumption and emissions. These are heavily dependent on the driver's behavior, such as time of idling and might in reality differ greatly from the average value. However, as heavy-duty transportation systems consist of a diverse range of actors and vehicles with different operating logics, it is feasible to expect the chosen approach to 
usefully indicate the benefits from transitioning the heavy-duty vehicle fleet into running on renewable resource based gaseous fuels such as biomethane. Finally, it should be kept in mind that the amounts of biomethane available through both $\mathrm{AD}$ and wood gasification are purely theoretical - the actual available amounts are dependent on many contingencies such as the interest of farmers in collecting agricultural side streams (for the related, possible policy incentives, see below).

\section{Results and Discussion}

In this section, the availability of biomethane and potential number of trucks in the three scenarios examined are discussed in relation to current biomethane policies. In addition, recommendations for policy measures to enhance biogas utilization in the heavy truck fleet are presented.

\subsection{Amount of Biomethane Available}

According to [37] the energy consumption of a biogas plant itself is $24 \%$ of the energy content. Consequently, the biomethane from AD available for use as transport fuel (10 MW minus the plant energy need) is 7.4 TWh. The amount of biomethane available from wood gasification was based on an estimate of $4 \mathrm{Mm}^{3}$ of wood [35] with a moisture content of $30 \%$. The mass of $4 \mathrm{Mm}^{3}$ of wood was calculated to be $952,000 \mathrm{t}$, with a total LHV of $3509 \mathrm{GWh}$. The LHV of product gas from gasification was calculated Equation (1) to be $2456 \mathrm{GWh}$. The calculated amount of total biomethane available $\left(\mathrm{CH}_{4}\right.$ directly from gasification and from $\mathrm{CO}$ plus $\mathrm{CO}_{2}$ methanation reaction Equations (2) and (3) resulted in 2147 GWh of energy. Therefore, the total amount of biomethane available for heavy duty transport would be $9.5 \mathrm{TWh}$.

\subsection{Vehicle Class Scenarios}

Calculations of the vehicle class scenarios were based on the current number of trucks and average mileages (Table 2) as well as the average energy consumption calculated for each vehicle class. The energy consumption of biomethane fuelled trucks per vehicle class Equation (4) with the assumed $18 \%$ lower efficiency [11] would result in $257 \mathrm{kWh} / 100 \mathrm{~km}$ (LD trucks), $454 \mathrm{kWh} / 100 \mathrm{~km}$ (MD trucks) and $675 \mathrm{kWh} / 100 \mathrm{~km}$ (HD trucks). The numbers of trucks in each class and the respective average energy consumption for the examined scenarios are presented in Figure 2 and compared to the current heavy-duty transport vehicle fleet.
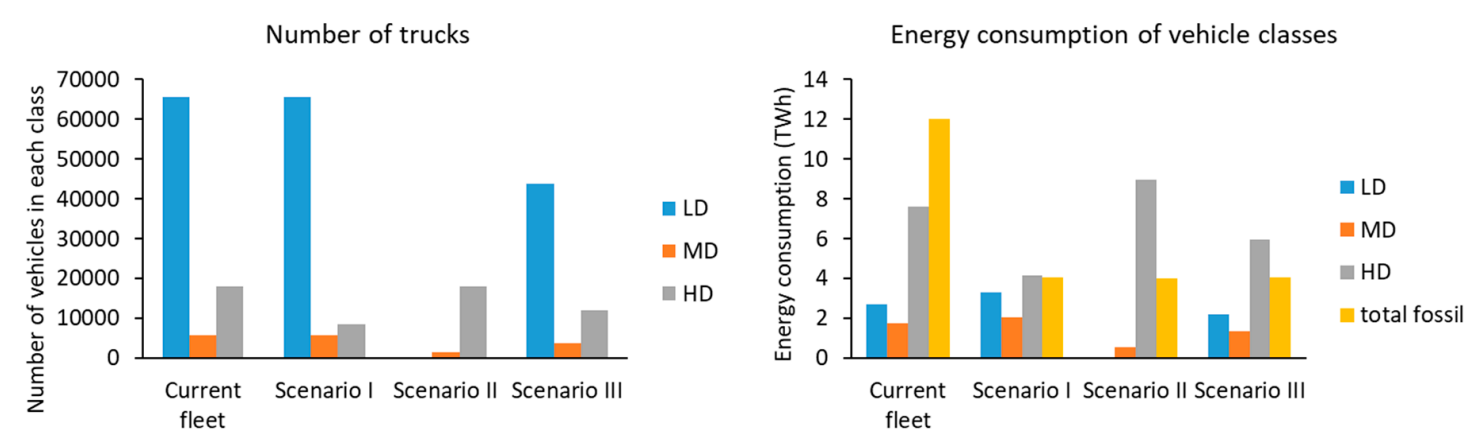

Figure 2. Number of trucks and energy consumption of vehicle classes for the scenarios. Note: for scenarios I-III the number of trucks and energy consumption in vehicle classes represent biomethane fuelled trucks with $18 \%$ higher energy consumption.

In scenario I, the available biomethane $(9.5 \mathrm{TWh})$ would suffice for all the LD trucks $(65,616)$ and MD trucks (5652) currently in traffic (Table 2), as well as $46 \%$ of HD trucks (8400).

In scenario II, the available biomethane (9.5 TWh) would suffice for all the HD trucks currently in traffic (18,123; Table 2) and for $26 \%$ of the MD trucks (1450). With HD trucks preferred in this scenario, no biomethane would be available for LD trucks. 
In scenario III, the biomethane would suffice for a $66 \%$ share of trucks currently in traffic (Table 2) divided between the three classes (LD 43,744, MD 3768, and HD 12,082). Assuming that up to 35\% of heavy transport in Finland could be electrified [7], in principle the entire volume of the country's heavy traffic could either run on biomethane or be electrified.

\subsection{Economic and $\mathrm{CO}_{2}$ Savings Analysis}

The overall costs of transforming the heavy-duty transport fleet to run on biomethane are difficult to estimate since, for example, the price of gas fuelled trucks depends on the accessories. The lack of gas fuelled vehicles and fuelling infrastructure also hampers cost estimation. Gas fuelled trucks may be up to $30 \%-40 \%$ more expensive than diesel fuelled trucks [10]. The availability of used gas trucks is currently limited, while renewing the whole truck fleet in Finland within a short timeframe is unrealistic. However, by investing in the fuelling station network and promoting investments in gas fuelled vehicles, a large share of the fleet could be gas fuelled in 10 to 20 years. Börjesson et al. [11] and Angelbratt [10] estimate slightly lower operating costs for liquefied gas fuelled vehicles than for diesel fuelled vehicles, but $15 \%-20 \%$ higher costs for compressed NG (or BG) fuelled vehicles, however, this depends heavily on the production costs of biomethane [11] — for AD biomethane, these are case and feedstock specific, while plants can charge gate fees [37]. With these limitations, we propose a rough estimate of the plant capacities, production costs needed, and the investments required.

Traffic fuel biomethane use in Finland was $30 \mathrm{GWh}$ [53] in 2017. Total biogas production (including collection from landfill sites) was approximately $700 \mathrm{GWh}$, and the number of production sites 71 [53]. This means that only approximately $8 \%$ of the techno-economic potential $(10 \mathrm{TWh})$ of biogas was utilized. There are currently no wood gasification plants in Finland. To produce the 9.5 TWh of biomethane for transport fuel with the assumed $8000 \mathrm{~h}$ yearly operational hours (see Section 2) would require investing in $1250 \mathrm{MW}$ capacity for $\mathrm{AD}$ plants and $265.5 \mathrm{MW}$ for wood gasification plants. The overall investment would amount to 5.5-9.1 billion $€$. This amount can be compared to the overall import of oil products, which in 2017 which was worth 8.4 billion $€$ [68]. The share of the investment annuity for AD biogas would be 24.3-50.9 €/MWh, and for gasification biomethane 75.9 $€ / \mathrm{MWh}$. Together with the assumed production costs [11], the total production cost for AD biomethane would be $81-108 € / \mathrm{MWh}$, and for gasification biomethane 148-190 $€ / \mathrm{MWh}$. The consumer price for diesel in 2018 was $152 € / M W h$, which makes biomethane a competitive product given the assumptions. Since the gasification plants investment costs are based on a pilot plant [47], it is likely that the cost of gasification for biomethane will decrease as the technology matures.

The sensitivity analysis showed (Figure 3) the costs of biomethane to be more sensitive to the investment costs than the production costs. In addition, the investment costs will likely decrease rather than increase with more frequent installations. However, one must bear in mind the dependence of production costs on feedstock costs [37]. Finally, the examination of the slope of sensitivities indicates how changes, for example in the chemical engineering index, or interest costs may also affect costs, yet these effects cannot be estimated in detail within the scope of this study.
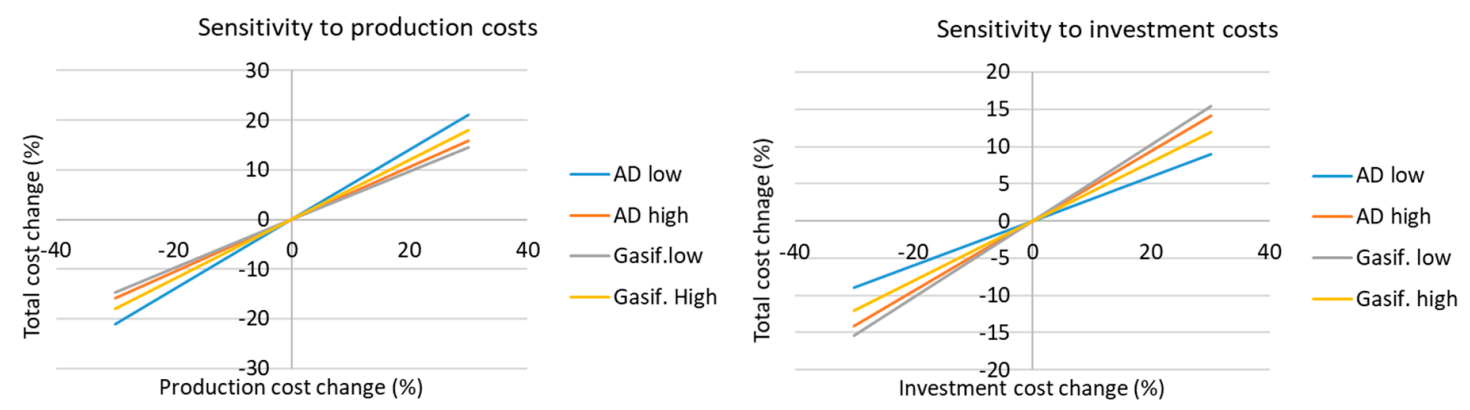

Figure 3. Biomethane overall cost sensitivity to production and investment cost. 
The total $\mathrm{CO}_{2}$-equivalent emissions and $\mathrm{NO}_{x}$ emissions for the scenarios examined (Figure 4) were calculated on the basis of average emissions for each vehicle class (Table 4), with the limitations discussed in Section 2.3. For scaling purposes, the $\mathrm{CO}_{2}$ emissions (Figure 4 are presented as $100 \mathrm{t} / \mathrm{a}$.

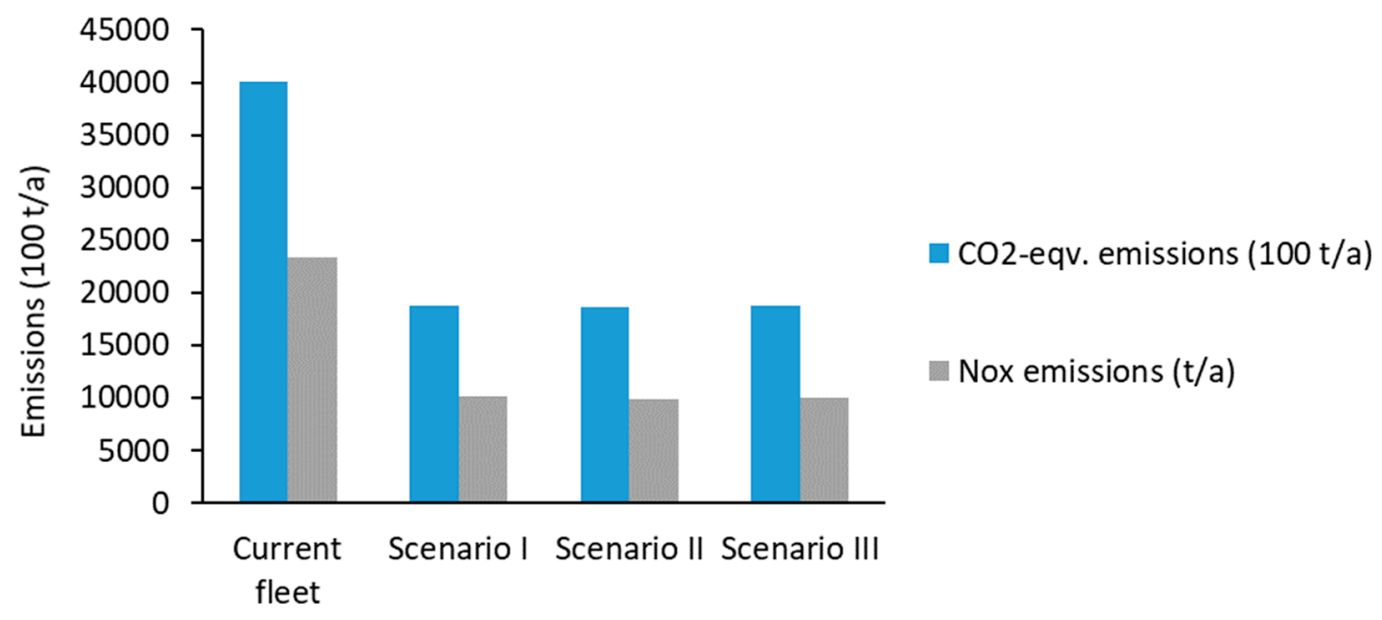

Figure 4. $\mathrm{CO}_{2}$-equivalent and $\mathrm{NOx}$ emissions for the scenarios examined and current truck fleet. Note: the $\mathrm{CO}_{2}$-equivalent emissions are presented on a scale of $100 \mathrm{t} / \mathrm{a}$ for scaling purposes.

Running as many trucks as possible with the 9.5 TWh of biomethane reduces $\mathrm{CO}_{2}$ emissions by more than 50\% (Figure 4) from 400,000 tons/a to 190,000 tons/a. The preferred vehicle class does not significantly affect emission reduction. Considering only the investment costs (5.5-9.1 billion $€$ ) of plants with the assumed $4 \%$ interest with a 20-year plant lifetime (annuity 0.0736 ), the cost of $\mathrm{CO}_{2}$-emission reduction would be 190-315 $€ /$ ton of $\mathrm{CO}_{2}$. While this may seem to be a high cost compared to the current prices of emission allowances, it is balanced by savings in the avoided importation of fossil fuels. A detailed analysis of the economic effects should be a subject of future research.

Similar results are observed in relation to $\mathrm{NO}_{\mathrm{x}}$ emissions (Figure 4). This means that the amount of emissions per vehicle class is compensated by the number of vehicles in the different scenarios. In other words, emission reduction benefits are greater in areas with many frequently driven vehicles. Given that HD vehicles are mainly used for long distance haulage between cities, utilizing biomethane in intra-city delivery traffic is preferable due to improvements in local air quality through diminished $\mathrm{NO}_{\mathrm{x}}$ emissions.

\subsection{Policy Instruments}

Despite recognition in the national energy strategy (see Section 1), the high technical potential and tangible emission savings enabled by biogas solutions (see Sections 2 and 3), no substantial progress in the transport use of gas has been made in recent decades in Finland [53]. The trends in the production of biogas, vehicle gas and the size of the gas operated vehicle fleet are relatively modest $[36,53]$. The sector faces a deadlock, as present and potential producers lack confidence in the market. Potential consumers in the transport sector for their part remain unsure of the availability of biogas. Resolution of the deadlock requires taking into account the whole production chain including both the supply and demand ends and the deployment of suitable policy instruments.

Biogas as a policy sector is difficult to organize effectively. The biogas production chain includes multiple use cases competing with each other (see Section 1). The established principles of technology neutrality and preference for market-based solutions make Finnish policy planning tricky in the biogas sector, as all use cases should be treated equally [35]. This is evident in the recent policy documents which, while recognizing the possibilities of domestic biogas production, remain very generic in terms of objectives and measures proposed [40]. Moreover, biogas faces a range of competitors and regulations in the transport use case in particular. Overall, the transport sector is difficult to govern [39], 
while in the passenger vehicle segment, biogas faces fierce competition from the growing number of electric vehicles (often supported by incentives directed at electricity production), and from drop-in biofuels compatible with contemporary petrol and diesel engines.

\subsubsection{Feasibility of Biogas Production}

Subsidies are crucial for the development of the biogas sector [69]. Biogas typically features an immature solution when compared with existing solutions with their own incumbent actors, established infrastructures and dominant rules [9]. In general, the competition from the fossil fuel sector faced by emerging renewable solutions is not fair [5], with numerous effects of historically accumulated direct and indirect subsidies.

The current policy instruments supporting the biogas sector in Finland focus heavily on the production end. The main instrument is investment grants for production facilities [70]. A separate scheme subsidizes biogas plants located on farms with a requirement to utilize the energy produced on agricultural activities on site [71]. Should the farm prioritize selling biogas to the transport sector, a separate company has to be formed in order to be eligible for an investment grant [40]. This, in turn, leads to some limitations in terms of investments covered and a lower level of financial support. Additionally, biogas and biomethane are currently supported through tax exemptions. Whereas investment grants are crucial for laying a solid economic foundation for the production of biogas, the growth of the whole biogas ecosystem can be greatly accelerated by subsidizing biomethane directly, or by adjusting taxation costs for competing fossil fuels in the transport sector [43]. However, taxation policies should avoid generating long-term unpredictability for the biogas sector [27]. In Finland, where investment grants and tax exemption for biogas currently exist, this would suggest focusing upon stabilizing biogas related policies and goals as producers and consumers alike value long-term predictability more than short-term subsidies [69]. As long as a comprehensive strategic niche management approach linking the energy, transport, agricultural, forestry, industrial and other sectors is largely lacking [72]—something that biomethane solutions usually require in the transport sector [9]—-many potential producers deem this market too uncertain.

To meet the biomethane potential identified in this study, currently unused feedstock potential needs to be enabled for biogas production. The bulk of the resource potential is located near farms, which often lack sufficient funding, the required know-how, and bargaining power to engage in economically feasible biogas production [73]. According to Lyng et al. [74], sizeable incentives are usually needed to make agricultural biomasses available for biogas production. Equally important would be consolidating the role of digestate as a byproduct to create strong value chains and maximize GHG emission reductions [74]. This integration option could be highly beneficial, especially for farms, but is simultaneously the most unlikely because of the increased costs [74]. To enable large-scale biogas production, feeding resources such as manure and other agricultural residues could also be supported [38]. Moreover, as farms are not linked to traditional chains of energy production, agricultural policies need coupling with energy policies. On regional and local levels, new business models are needed between energy producers and farms enabling better utilization of both biogas and digestate $[75,76]$. Careful planning of the whole supply chain has proven to be a key aspect for successful biogas systems in Danish conditions [73] but lags behind in Finland due to poor cross-sectoral co-operation between relevant actors [39]. However, encouraging examples such as that of the Biohauki company [77], suggest that local biomethane production from waste materials can indeed be feasible in Finland with proper planning and willing actors. Ultimately, the production scales needed for heavy-duty transport would most likely favour production in larger centralized co-digestion units. At the same time, gaining acceptance is easier for small plants as seen in some cases in Denmark, Italy and Germany [9]. 


\subsubsection{Fuelling Infrastructure and Vehicles}

The delivery system is the most vital part of the biogas chain by virtue of linking production with end use. Of the 41 gas filling stations in Finland, only four provide liquefied gas for heavy-duty vehicles [78]. This infrastructural limitation hampers most seriously the market entry of biogas fuelled vehicles [38]. This is particularly evident in the concentration of the heaviest part of the truck fleet using LNG-infrastructure on the coastal regions of Western and southern Finland, where both fuelling stations and LNG terminals are located [38]. The Eastern and Northern parts of Finland lack similar infrastructure. These limitations stem, at least partially, from the geography of the main commercial ports and the location of the natural gas grid in southern Finland. Uusitalo et al. [38] deem the limited natural gas grid a major hindrance to vehicle gas development. Meanwhile in Sweden, biogas ecosystems have evolved especially in the Mälardalen area, located outside of the gas grid [43]. While access to the natural gas grid could decrease the costs of compression and help in overcoming transport distances, alternative infrastructural solutions exist. Gasum, the state-controlled gas company operating the natural gas grid plans to significantly expand the LNG-fuelling infrastructure suitable for heavy-duty vehicles [79].

To expand the market, or the gas operated truck fleet, additional subsidies for heavy-duty vehicles running on biomethane should be considered. While biomethane is currently exempt from fuel tax, the vehicle tax for trucks does not differentiate between fuels [80]. Differentiating between fuels, followed by a lowering of the vehicle tax for gas-operated trucks in contrast to diesel fuelled trucks, could greatly improve the feasibility of vehicles and create demand for vehicle gas. The size of the vehicle fleet could also be expanded by offering grants for gas operated vehicles or low-emission vehicles in general [81]. Public authorities can help to create stable demand for vehicle gas and demonstrate the potential of gas-fuelled vehicles, for example by deploying them in public sector tasks such as waste collection. In fact, public authorities can support the overall development of local biogas systems as they have leverage over both the supply and demand sides [28].

Here, the importance of strategic niche management [9] is again evident, since merely offering investment grants for the production of biogas may channel that production towards the non-transport uses of biogas (heat and power production; see Section 1 above) in the absence of public policies generating sufficient initial demand for vehicle gas [69]. From this perspective, subsidizing energy carriers, delivery systems and/or the acquisition of vehicles would seem to be an obvious choice. However, subsidizing end-use only can have the unintended consequence of promoting the usage of natural gas in place of biogas owing to the current price advantage of the former. The question regarding natural gas in relation to biomethane is decidedly ambiguous. As noted above, biomethane and natural gas can be transported and fuelled using the same infrastructure and are mutually substitutable fuels.

Increased use of natural gas in heavy-duty vehicles could actually serve the needs of the biomethane sector as it could accelerate the development of gas infrastructure [82], strengthen the availability of vehicle gas in general and decrease the fuelling costs of gas-fuelled vehicles. A higher number of gas-operated vehicles would in turn provide stable demand for vehicle gas, thereby incentivizing biogas producers to upgrade their product into vehicle gas. However, it is uncertain if consumers would eventually switch to biomethane even with higher production volumes. In heavy-duty transportation, the fuel volumes are significantly larger than in passenger transportation; hence the price at the fuel pump is significant. This means that biomethane needs to become competitive with natural gas. Subsidies granted to encourage the usage of renewable and domestic energy resources may otherwise end up promoting imported fossil fuels instead.

\subsubsection{Policy Cohesion-Towards the National Biogas Plan}

An incoherent and unstable policy framework is a frequently overlooked constraint on the development of biogas systems [27]. That know-how, institutional capacity, and supply-side coordination have recently been identified as the main constraints for bioenergy in general on the European level [9] speaks for the need for policy cohesion. Although biogas amply supports the 
contemporary Finnish strategies for bio-economy and circular economy and the national targets for a higher share of renewable energy and energy independence, these targets and the respective policy instruments are neither well defined nor aligned [39,40]. Uncertainty as to how political institutions treat biogas and gas operated vehicles hampers the development of forest-based biogas, in particular due to the high capital costs and intensive energy consumption inherent in the gasification process [83]. Such uncertainty quite possibly deters potential investors and negates innovations in the sector [39].

Finland has yet to introduce a systematic national plan for biogas utilization, in contrast to the situation in neighbouring Sweden [84] and Norway [85]. While the Norwegian plan may not be as detailed as its Swedish counterpart, the mere existence of a formal plan encourages actors in the biogas sector. At best, the preparation process of such a plan enables systematic account to be taken of the various actors' concerns about the biogas value chain. This is what Finland is currently lacking-actors from different sectors hold highly diverse views on the subject and their roles, and biogas related issues remain to be addressed from multiple narrow perspectives [39]. A report by a think tank close to the government identifies four different paths for the use of biogas, one of them transport-centred [75]. However, this report so far lacks political recognition and follow-up. A process leading to the adoption of a national biogas strategy could kick start a much needed robust, comprehensive and cross-sectoral policy framework for the Finnish biogas sector.

It is suggested here that such a process could proceed from an effort to improve the profitability of agricultural production in Finland, taken that currently $36 \%$ of the turnover is subsidized [86]. First, national regulation should better consolidate the use of digestate, a byproduct from AD biogas production, as a fertilizer to enhance the portfolio of business models of farms. The exploitation of digestate requires careful control of the whole process from production to use in the field, and the drafting of respective national standards on the basis of existing international guidelines [87]. Biogas producers frequently struggle to find commercial uses for digestate, and farmers instead rely on mineral fertilizers. This in turn leaves biogas producers with an excess resource, which has negative implications for the sector's emissions and the national security of supplies. Second, supporting consolidation in the agricultural sector by means of incentivizing co-operatives between farms and energy producers would additionally improve the business model of biogas production and digestate exploitation as a fertilizer. The average Finnish livestock farm so far produces too little manure to make the initial investment cost-effective [88]. In short, at the production end, a national plan should propose biogas-specific investment support schemes directed at farms and co-operatives of farms to create economies of scale. Third, attaining the goal of improved policy cohesion would require simultaneous and coordinated measures regarding the feeding of biogas into the distribution network, for example direct subsidies, while at the consumption end vehicle acquisition could also be directly subsidized (see Sections 3.4.1 and 3.4.2 above).

Overall, proceeding from the views of different actors along the production chain of biogas and bringing them under the same framework would highlight cross-sectoral problems and render them more easily solvable. Simultaneously the formulation of a biogas strategy should be based on an analysis of the current system structure on local and regional levels [27]. A biogas strategy must be ambitious to attract the actors of the value chain, but realistic in terms of its analysis of the structures of the society in question. In Finland, where regional differences in available feedstock, transport distances, existing infrastructure and vehicle fuel demand can be deemed substantial, understanding the local level realities will be a crucial starting point in building the national biogas strategy.

\section{Conclusions}

This paper examined the potential of transforming the heavy-duty transport sector in Finland into a biomethane fuelled fleet. Biomethane can help to reduce GHG emissions in the transport sector since it can be produced from waste materials such as sludge, agricultural waste or forest industry wastes without significant effects on the carbon sink. Moreover, it is compatible with natural gas 
fuelled infrastructures and technologies, which enables direct substitution of a large share of fossil fuels in transport.

The results suggest a great technical potential in this respect; in the second scenario, where the target truck class was HD, then MD and as many LD trucks as possible, the whole heavy-duty truck fleet and $26 \%$ of the medium duty fleet could run on biomethane. Alternatively, in the third scenario, where the share of biomethane fuelled vehicles was divided equally between all classes (\%), $66 \%$ of all truck classes could use biomethane. Combined with the potential of electrification within the heavy-duty sector [7], the use of biomethane would make it possible to run the entire truck traffic without the use of fossil fuels. By maximizing the biomethane fuelled heavy transport fleet, the $\mathrm{CO}_{2}$ emissions could be reduced 50\% compared with the current diesel fuelled fleet. A rough estimation including only the investment costs of biomethane production suggested that the respective reduction of $\mathrm{CO}_{2}$ emissions in the Finnish case would cost 190-315 $€ /$ ton of $\mathrm{CO}_{2}$ saved.

The constraints for the transition concentrate on policy cohesion. This includes insufficient financial incentives and uncertain business models for investors in AD biogas production, which currently hinder the economic feasibility of biogas production. Further interlinked problems include limited fuelling infrastructure and a lack of demand in the transport sector. In the absence of a stable and coherent policy framework accounting for the entire production chain, distribution and use of biogas as a transport fuel, the biomethane sector struggles to meet its potential.

The transition to biomethane in heavy-duty transport requires substantial investments, political leadership, and the respective deployment of coherent, strategic niche management policies. Regional realities and local actors should also be taken better into account as part of a national biogas strategy, which should carefully align direct and indirect policy instruments into a coherent framework.

Author Contributions: Conceptualization, K.A. and P.A.; methodology, A.P. and K.A.; formal analysis, A.P.; writing-original draft preparation, A.P. and K.A.; writing—review and editing, P.A., M.K., J.K.; visualization, A.P.; supervision, P.A. and J.K.

Funding: Strategic Research Council at the Academy of Finland: 314319.

Acknowledgments: This work was supported by the Strategic Research Council at the Academy of Finland, project Transition to a resource efficient and climate neutral electricity system (EL-TRAN) grant number 314319 as well as the Fortum Foundation (personal grant for Pääkkönen).

Conflicts of Interest: The authors declare no conflict of interest. The funders had no role in the design of the study; in the collection, analyses, or interpretation of data; in the writing of the manuscript, or in the decision to publish the results.

\section{References}

1. Sims, R.; Schaeffer, R.; Creutzig, F.; Cruz-Núñez, X.; D’Agosto, M.; Dimitriu, D.; Figueroa Meza, M.J.; Fulton, L.; Kobayashi, S.; Lah, O.; et al. Transport. In Climate Change 2014: Mitigation of Climate Change. Contribution of Working Group III to the Fifth Assessment Report of the Intergovernmental Panel on Climate Change; Edenhofer, O., Pichs-Madruga, R., Sokona, Y., Farahani, E., Kadner, S., Seyboth, K., Adler, A., Baum, I., Brunner, S., Eickemeier, P., et al., Eds.; Cambridge University Press: Cambridge, UK; New York, NY, USA, 2014.

2. International Energy Agency. Global Energy and $\mathrm{CO}_{2}$ Status Report 2017; International Energy Agency: Paris, France, 2018.

3. International Energy Agency. Key World Energy Statistics; International Energy Agency: Paris, France, 2017.

4. Det Kongelige Samferdselsdepartement. Meld. St. 33 (2016-2017)—Nasjonal Transportplan 2018-2029; Det Kongelige Samferdselsdepartement: Voss, Norway, 2017.

5. Ridjan, I.; Mathiesen, B.V.; Connolly, D.; Duić, N. The feasibility of synthetic fuels in renewable energy systems. Energy 2013, 57, 76-84. [CrossRef]

6. Mathiesen, B.V.; Lund, H.; Connolly, D.; Wenzel, H.; Østergaard, P.A.; Möller, B.; Nielsen, S.; Ridjan, I.; Karnøe, P.; Sperling, K.; et al. Smart Energy Systems for coherent 100\% renewable energy and transport solutions. Appl. Energy 2015, 145, 139-154. [CrossRef] 
7. Liimatainen, H.; van Vliet, O.; Aplyn, D. The potential of electric trucks - An international commodity-level analysis. Appl. Energy 2019, 236, 804-814. [CrossRef]

8. Baldino, C.; Nikita, P.; Searle, S.; Christensen, A. The Potential for Low-Carbon Renewable Methane in Heating, Power, and Transport in the European Union; Working Paper 2017-26; The International Council on Clean Transportation: Berlin, Germany, 2018.

9. Capodaglio, A.G.; Callegari, A.; Lopez, M.V. European framework for the diffusion of biogas uses: Emerging technologies, acceptance, incentive strategies, and institutional-regulatory support. Sustainability 2016, 8 , 298. [CrossRef]

10. Angelbratt, A.; Berggren, A. Potentials of LBM in Europe. LNG Blue Corridors Deliverable 3.9. 2005. Available online: http://ngbc.eu/system/files/deliverable_attachments/LNG\%20BC\%20D3.9\%20Potential\% 20of\%20LBM\%20in\%20Europe\%20UPDATE.pdf (accessed on 28 August 2019).

11. Börjesson, P.; Lantz, M.; Andersson, J.; Björnsson, L.; Fredriksson Möller, B.; Fröberg, M.; Hanarp, P.; Hulteber, C.; Iverfeldt, E.; Lundgren, J.; et al. Methane as Vehicle Fuels-A Well-to-Wheel Analysis (METDRIV); f3 The Swedish Knowledge Centre for Renewable Transportation Fuels: Göteborg, Sweden, 2016.

12. IRENA Biogas for Road Vehicles: Technology Brief; International Renewable Energy Agency: Abu Dhabi, UAE, 2018.

13. Khan, M.I.; Yasmin, T.; Shakoor, A. Technical overview of compressed natural gas (CNG) as a transportation fuel. Renew. Sustain. Energy Rev. 2015, 51, 785-797. [CrossRef]

14. Lyng, K.A.; Brekke, A. Environmental Life Cycle Assessment of Biogas as a Fuel for Transport Compared with Alternative Fuels. Energies 2019, 12, 532. [CrossRef]

15. Thiruvengadam, A.; Besch, M.; Padmanaban, V.; Pradhan, S.; Demirgok, B. Natural gas vehicles in heavy-duty transportation-A review. Energy Policy 2018, 122, 253-259. [CrossRef]

16. Cucchiella, F.; D’Adamo, I.; Gastaldi, M.; Massimo, G.; Idiano, D.A.; Federica, C. Biomethane: A renewable resource as vehicle fuel. Resources 2017, 6, 58. [CrossRef]

17. Meyer, A.K.P.; Ehimen, E.A.; Holm-Nielsen, J.B. Future European biogas: Animal manure, straw and grass potentials for a sustainable European biogas production. Biomass Bioenergy 2018, 111, 154-164. [CrossRef]

18. Bienert, K.; Schumacher, B.; Arboleda, M.R.; Billig, E.; Shakya, S.; Rogstrand, G.; Zielinski, M.; Debowski, M. Multi-Indicator Assessment of Innovative Small-Scale Biomethane Technologies in Europe. Energies 2019, 12, 1321. [CrossRef]

19. Kalinichenko, A.; Havrysh, V.; Perebyynis, V. Evaluation of Biogas Production and Usage Potential. Ecol. Chem. Eng. 2016, 23, 387. [CrossRef]

20. Connolly, D.; Mathiesen, B.V.; Ridjan, I. A comparison between renewable transport fuels that can supplement or replace biofuels in a 100\% renewable energy system. Energy 2014, 73, 110-125. [CrossRef]

21. Prussi, M.; Padella, M.; Conton, M.; Postma, E.D.; Lonza, L. Review of technologies for biomethane production and assessment of Eu transport share in 2030. J. Clean. Prod. 2019, 222, 565-572. [CrossRef]

22. Scania. Scania Adds Gas Truck for Longer Transports. Press Release 8 November 2017. Available online: https:/www.scania.com/group/en/scania-adds-gas-truck-for-longer-transports/ (accessed on 20 November 2018).

23. Volvo Trucks. New Trucks from Volvo Running on LNG Offer the Same Performance as Diesel, but with 20-100\% Lower $\mathrm{CO}_{2}$ Emissions. Available online: https://www.volvotrucks.com/en-en/news/press-releases/ 2017/oct/pressrelease-171003.html (accessed on 20 November.2018).

24. IVECO New Stralis NP Brochure. Available online: https://www.iveco.com/uk/products/pages/gas-poweredfor-long-haulage-new-stralis.aspx (accessed on 20 November 2018).

25. Hijazi, O.; Munro, S.; Zerhusen, B.; Effenberger, M. Review of life cycle assessment for biogas production in Europe. Renew. Sustain. Energy Rev. 2016, 54, 1291-1300. [CrossRef]

26. Rajendran, K.; O'Gallachoir, B.; Murphy, J.D. The combined role of policy and incentives in promoting cost efficient decarbonisation of energy: A case study for biomethane. J. Clean. Prod. 2019, 219, 278-290. [CrossRef]

27. Ammenberg, J.; Anderberg, S.; Lönnqvist, T.; Grönkvist, S.; Sandberg, T. Biogas in the transport sector: Actor and policy analysis focusing on the demand side in the Stockholm region. Resour. Conserv. Recycl. 2018, 129, 70. [CrossRef]

28. Lönnqvist, T.; Sanches-Pereira, A.; Sandberg, T. Biogas potential for sustainable transport-a Swedish regional case. J. Clean. Prod. 2015, 108, 1105-1114. [CrossRef]

29. Jensen, S.S.; Winther, M.; Jørgensen, U.; Møller, H.B. Scenarios for Use of Biogas for Heavy-Duty Vehicles in Denmark and Related GHG Emission Impacts; Trafikdage: Aalborg, Denmark, 2017. 
30. Uusitalo, V.; Soukka, R.; Horttanainen, M.; Niskanen, A.; Havukainen, J. Economics and greenhouse gas balance of biogas use systems in the Finnish transportation sector. Renew. Energy 2013, 51, 132-140. [CrossRef]

31. Gerring, J. Case Study Research: Principles and Practices; Cambridge University Press: Cambridge, UK, 2007. [CrossRef]

32. European Automobile Manufacturers Association. ACEA Report: Vehicles in Use-Europe 2018; European Automobile Manufacturers Association: Southfield, MI, USA, 2018.

33. Eurostat. Annual Road Freight Transport, by Load Capacity of Vehicle (Mio Tkm, Mio Veh-km, 1000 Jrnys). Available online: http://appsso.eurostat.ec.europa.eu/nui/submitViewTableAction.do (accessed on 19 June 2019).

34. Official Statistics of Finland (OSF). Greenhouse Gases [e-publication]. ISSN=1797-6065. Available online: http://www.stat.fi/til/khki/index_en.html (accessed on 4 December 2018).

35. Government of Finland. Government report on the National Energy and Climate Strategy for 2030. In Publications of the Ministry of Economic Affairs and Employment 12/2017; Government of Finland: Helsinki, Finland, 2017.

36. Finnish Transport and Communications Agency. Open Vehicle Data. Available online: https://www.trafi.fi/ en/information_services/open_data (accessed on 5 June 2018).

37. Marttinen, S.; Luostarinen, S.; Winquist, E.; Timonen, K. Rural Biogas: Feasibility and Role in Finnish Energy System; Cluster for Energy and Environment: Helsinki, Finland, 2015.

38. Uusitalo, V.; Havukainen, J.; Soukka, R.; Väisänen, S.; Havukainen, M.; Luoranen, M. Systematic approach for recognizing limiting factors for growth of biomethane use in transportation sector-A case study in Finland. Renew. Energy 2015, 80, 479-488. [CrossRef]

39. Huttunen, S.; Kivimaa, P.; Virkamäki, V. The need for policy coherence to trigger a transition to biogas production. Environ. Innov. Soc. Transit. 2014, 12, 14-30. [CrossRef]

40. Winquist, E.; Rikkonen, P.; Pyysiäinen, J.; Varho, V. Is biogas an energy or a sustainability product?Business opportunities in the Finnish biogas branch. J. Clean. Prod. 2019, 233, 1344-1354. [CrossRef]

41. Börjesson, P. Potential för Ökad Tillförsel och Avsättning av Inhemsk Biomassa i en Växande Svensk Bioekonomi; Lund University, Department of Technology and Society, Environmental and Energy Systems Studies: Lund, Sweeden, 2016; Volume 97, p. 85.

42. Lyng, K.-A. Reduction of Environmental Impacts Through Optimisation of Biogas Value Chains; Drivers, Barriers and Policy Development, Norwegian University of Life Sciences: Ås, Norway, 2018.

43. Larsson, M.; Grönkvist, S.; Alvfors, P. Upgraded biogas for transport in Sweden-effects of policy instruments on production, infrastructure deployment and vehicle sales. J. Clean. Prod. 2016, 112, 3774-3784. [CrossRef]

44. Aro, K.; Rautiainen, A.; Talus, K.; Pääkkönen, A.; Aalto, P.; Kojo, M.; Rönkkö, T. Voiko raskas tieliikenne siirtyä biokaasuun? [Can Heavy-Duty Road Transport Switch over to Biogas?]. EL-TRAN Analysis 6/2018. Available online: http://urn.fi/URN:ISBN:978-952-03-0879-7 (accessed on 28 August 2019).

45. Kilpeläinen, S.; Aalto, P.; Toivanen, P.; Lehtonen, P.; Holttinen, H. How to Achieve a More Resource-Efficient and Climate-Neutral Energy System by 2030? Views of Nordic Stakeholders: Views of Nordic Stakeholders. Rev. Policy Res. 2019, e0001. [CrossRef]

46. Alamia, A.; Magnusson, I.; Johnsson, F.; Thunman, H. Well-to-wheel analysis of bio-methane via gasification, in heavy duty engines within the transport sector of the European Union. Appl. Energy 2016, 170, 445-454. [CrossRef]

47. Alamia, A.; Larsson, A.; Breitholtz, C.; Thunman, H. Performance of large-scale biomass gasifiers in a biorefinery, a state-of-the-art reference: Evaluation of the GoBiGas gasifier. Int. J. Energy Res. 2017, 41, 2001-2019. [CrossRef]

48. Kapdi, S.S.; Vijay, V.K.; Rajesh, S.K.; Prasad, R. Biogas scrubbing, compression and storage: Perspective and prospectus in Indian context. Renew. Energy 2005, 30, 1195-1202. [CrossRef]

49. Ryckebosch, E.; Drouillon, M.; Vervaeren, H. Techniques for transformation of biogas to biomethane. Biomass Bioenergy 2011, 35, 1633-1645. [CrossRef]

50. Patterson, T.; Esteves, S.; Dinsdale, R.; Guwy, A. An evaluation of the policy and techno-economic factors affecting the potential for biogas upgrading for transport fuel use in the UK. Energy Policy 2011, 39, 1806-1816. [CrossRef]

51. Kalinci, Y.; Hepbasli, A.; Dincer, I. Biomass-based hydrogen production: A review and analysis. Int. J. Hydrogen Energy 2009, 34, 8799-8817. [CrossRef] 
52. Rönsch, S.; Schneider, J.; Matthischke, S.; Schlüter, M.; Götz, M.; Lefebvre, J.; Prabhakaran, P.; Bajohr, S. Review on methanation - From fundamentals to current projects. Fuel 2016, 166, 276-296. [CrossRef]

53. Huttunen, M.; Kuittinen, V.; Lampinen, A. Finnish National Biogas Statistics—Data Year 2017; University of Eastern Finland: Joensuu, Finland, 2018.

54. Wilen, C.; Moilanen, A.; Kurkela, E. Biomass Feedstock Analyses; VTT: Espoo, Finland, 1996; Volume 282.

55. Pfeifer, C.; Puchner, B.; Hofbauer, H. Comparison of dual fluidized bed steam gasification of biomass with and without selective transport of $\mathrm{CO}_{2}$. Chem. Eng. Sci. 2009, 64, 5073-5083. [CrossRef]

56. Göransson, K.; Söderlind, U.; He, J.; Zhang, W. Mittuniversitetet; Institutionen för naturvetenskap, t.o.m.; Fakulteten för naturvetenskap, t.o.m. Review of syngas production via biomass DFBGs. Renew. Sustain. Energy Rev. 2011, 15, 482-492. [CrossRef]

57. Asadullah, M. Biomass gasification gas cleaning for downstream applications: A comparative critical review. Renew. Sustain. Energy Rev. 2014, 40, 118-132. [CrossRef]

58. Molino, A.; Braccio, G. Synthetic natural gas SNG production from biomass gasification-Thermodynamics and processing aspects. Fuel 2015, 139, 425-429. [CrossRef]

59. Kopyscinski, J.; Schildhauer, T.J.; Biollaz, S.M.A. Production of synthetic natural gas (SNG) from coal and dry biomass-A technology review from 1950 to 2009. Fuel 2010, 89, 1763-1783. [CrossRef]

60. VTT Technical Research Centre of Finland Ltd. LIPASTO Unit Emissions-Database. Available online: www.lipasto.vtt.fi/yksikkopaastot/ (accessed on 3 December 2018).

61. Ristikartano, J.; Ilkkanen, P.; Tervonen, J.; Lapp, T. Nationwide Road Traffic Forecast 2030; Finnish Transport Agency: Helsinki, Finland, 2014.

62. Niinikoski, M.; Moilanen, P. Developing the Calculation of Road Transport Performance; Finnish Transport Agency, Transport and Land Use: Helsinki, Finland, 2017.

63. Nylund, N.-O. Heavy-Duty Vehicles: Safety, Environmental Impacts and New Technology (RASTU); Annual Report 2007; VTT: Espoo, Finland, 2008.

64. Liimatainen, H.; Stenholm, P.; Tapio, P.; McKinnon, A. Energy efficiency practices among road freight hauliers. Energy Policy 2012, 50, 833-842. [CrossRef]

65. Finnish Transport Agency. Finnish Road Statistics 2016. In Statistics from the Finnish Transport Agency 4/2017; Finnish Transport Agency: Helsinki, Finland, 2017.

66. IRENA Biomass for Power Generation. Renewable Energy Technologies: Cost Analysis Series; International Renewable Energy Agency: Abu Dhabi, UAE, 2012.

67. Official Statistics of Finland (OSF). Energy Prices [e-publication]. ISSN=1799-800X. 4th Quarter 2018. Available online: http://www.stat.fi/til/ehi/2018/04/ehi_2018_04_2019-03-13_tie_001_en.html (accessed on 13 March 2019).

68. Finnish Customs. Finnish International Trade 2017 Figures and Diagrams. Finnish Customs Statistics. Available online: https://tulli.fi/en/statistics/key-figures-and-graphics (accessed on 11 January 2019).

69. Eker, S.; van Daalen, E. A model-based analysis of biomethane production in the Netherlands and the effectiveness of the subsidization policy under uncertainty. Energy Policy 2015, 82, 178-196. [CrossRef]

70. Business Finland. Energy Aid. Climate- and Environment-Friendly Investment and Investigation Projects. Available online: https:/www.businessfinland.fi/en/for-finnish-customers/services/funding/energy-aid/ (accessed on 27 May 2019).

71. Finnish Food Authority. Maatalouden Investointituet [Investment grants for agriculture]. Available online: https://www.ruokavirasto.fi/viljelijat/tuet-ja-rahoitus/maatalouden-investointituet/ (accessed on 27 May 2019).

72. Kampman, B.; Leguijt, C.; Scholten, T.; Tallat-Kelpsaite, J.; Brückmann, R.; Maroulis, G.; Lesschen, J.P.; Meesters, K.; Sikirica, N.; Elbersen, B. Optimal Use of Biogas from Waste Streams-An Assessment of the Potential of Biogas from Digestion in the EU Beyond 2020; European Commission: Brussels, Belgium, 2016.

73. Jensen, I.G.; Münster, M.; Pisinger, D. Optimizing the supply chain of biomass and biogas for a single plant considering mass and energy losses. Eur. J. Oper. Res. 2017, 262, 744-758. [CrossRef]

74. Lyng, K.-A.; Stensgård, A.E.; Hanssen, O.J.; Modahl, I.S. Relation between greenhouse gas emissions and economic profit for different configurations of biogas value chains: A case study on different levels of sector integration. J. Clean. Prod. 2018, 182, 737-745. [CrossRef]

75. Mutikainen, M.; Sormunen, K.; Paavola, H.; Haikonen, T.; Väisänen, M. Biokaasusta kasvua-Biokaasuliiketoiminnan ekosysteemien mahdollisuudet; Sitra: Helsinki, Finland, 2016. 
76. Skovsgaard, L.; Jensen, I.G. Recent trends in biogas value chains explained using cooperative game theory. Energy Econ. 2018, 74, 503-522. [CrossRef]

77. Biohauki Oy. Company Web Page. Available online: http://www.biohauki.fi/ (accessed on 13 February 2019).

78. Gasum. Gas Filling Stations. Available online: https://www.gasum.com/en/For-private-customers/Fill-upon-gas/Gas-filling-stations/ (accessed on 19 December 2018).

79. Gasum. Heavy-Duty Road Transport Entering the Age of Gas: Nordic Countries to Get a Network of 50 Filling Station. Available online: https://www.gasum.com/en/About-gasum/for-the-media/News/2018/heavy-dutyroad-transport-entering-the-age-of-gas-nordic-countries-to-get-a-network-of-50-filling-stations/ (accessed on 27 November 2018).

80. Act on Vehicle Tax (1281/2003). Available online: http://www.finlex.fi/fi/laki/ajantasa/2003/20031281 (accessed on 28 August 2019).

81. NGV Natural Gas for Trucks Promoted by German Transport Ministry. Available online: https://www. ngvglobal.com/blog/natural-gas-for-trucks-promoted-by-german-transport-ministry-0617 (accessed on 11 January 2019).

82. Dominiguez, J. Liquefied Biomethane Experiences-DRAFT. LNG Blue Corridors Deliverable 3.6. 2014. Available online: http://ngbc.eu/system/files/deliverable_attachments/LNG\%20BC\%20D\%203.6\% 20Biomethane\%20experiences.pdf. (accessed on 28 August 2019).

83. Lönnqvist, T.; Grönkvist, S.; Sandberg, T. Forest-derived methane in the Swedish transport sector: A closing window? Energy Policy 2017, 105, 440-450. [CrossRef]

84. Swedish Gas Association. Proposal for National Biogas Strategy 2.0; Swedish Gas Association: Energigas Sverige, Stockholm, 2018.

85. Klima-og Miljødepartement. Nasjonal Tverrsektoriell Biogasstrategi; Klima-og Miljødepartement: Oslo, Norway, 2014.

86. Natural Resources Institute Finland. Economydoctor. Agriculture and Horticulture. Available online: https://portal.mtt.fi/portal/page/portal/economydoctor/farm_economy/timeline/income_statement (accessed on 19 June 2019).

87. Lukehurst, C.T.; Frost, P.; Al Seadi, T. Utilization of Digestate from Biogas Plants as Biofertilizer; IEA Bioenergy: Paris, France, 2010.

88. Karunen, L. The Potentials of Producing Biogas Out of Farmyard Manure in Northern Middle Finland; Jyväskylä University of Applied Sciences: Berlin, Germany, 2010.

(C) 2019 by the authors. Licensee MDPI, Basel, Switzerland. This article is an open access article distributed under the terms and conditions of the Creative Commons Attribution (CC BY) license (http://creativecommons.org/licenses/by/4.0/). 